\title{
Inquiry Training Learning Model Assisted by Google Classroom to Improve Creative Thinking Skills of Senior High School Students
}

\author{
M. Helmi Hariadi ${ }^{1}$, Jumadi ${ }^{2}$, Insih Wilujeng ${ }^{3}$, Heru Kuswanto ${ }^{4}$, Wulandari ${ }^{5}$, \\ Sri Sundari6 \\ 1,2,3,4,5Masters in Physics Education, Postgraduate-Universitas Negeri Yogyakarta, Indonesia \\ ${ }^{6}$ SMA Negeri 1 Banguntapan, Bantul, DI Yogyakarta, Indonesia \\ e-mail: mhhariadi@yahoo.co.id
}

\begin{abstract}
This study aims at determining the effect of the inquiry training learning model assisted by Google Classroom in improving students' creative thinking skills. By using a quasi-experimental design, 32 students of SMAN 1 Banguntapan were involved in this study. The instrument test was an essay test to measure creative thinking skills. The first step of the study was given the pretest, then face-toface learning and online learning at the time agreed upon with students. The final stage was carried out posttest to see the achievement of the score after treatment. The results showed that the gain scores of creative thinking skills in students are categorized into three, namely: $62 \%$ of students with low category gain scores, 31\% of students with moderate category gain scores, and $7 \%$ of students with high category gain scores. The average score of gain of creative thinking ability was 0.3 , which was in the medium category. Based on these results, further research is needed with an emphasis on optimizing the use of Google Classroom and confirming knowledge construction in face-to-face learning.
\end{abstract}

Keywords: Creative Thinking; Google Classroom; Inquiry Training

\section{Introduction}

The domain of Physics, which is based on experiments, research, hypotheses, and thinking using a new perspective, can function as an excellent foundation and can lead to situations that allow developing creativity (Klieger \& Sherman, 2015). Creative thinking skills are one of the skills needed in the 21st century (Nurcahyanto \& Supahar, 2015). Creative thinking has become an essential element in everyday life. Therefore educators play a significant role in encouraging creative thinking skills, so educators are also required to be creative, open to creative ideas, and must support the creative process (Bakir \& Öztekin, 2014).

Creative thinking is a set of multi-dimensional components that lead individuals or groups to the generation of new ideas that have value (Corazza, 2016). Creative thinking skills include aspects of fluency, flexibility, elaboration, and originality (Malik, Setiawan, Suhandi, \& Permanasari, 2017). Indicators of creative thinking, according to Hanni, Muslim, Hasanah, \& Samsudin (2018) is showed in Table 1.

Table 1. Indicators of Creative Thinking Skills

\begin{tabular}{ll}
\hline \multicolumn{1}{c}{ Indicators of Creative Thinking } & \multicolumn{1}{c}{ Description } \\
\hline Fluency & Give lots of questions \\
Flexibility & Produce various ideas, answers, or questions \\
Originality & Produce new and unique phrases \\
Elaboration & Able to enrich and build ideas \\
\hline
\end{tabular}

Learning activities in schools have not fully facilitated students to develop creative thinking skills (Nurcahyanto \& Supahar, 2015). It is supported by the results of interviews with Physics teachers who stated that practicum is rarely done in Physics learning. The real experience of students in learning can be an effort to improve the creative thinking skills so that learning must be done using a student-centered learning model (Yusnaeni, Corebima, SUsilo, \& Zubaidah, 2017). On the other hand, the practicum method is effective learning that can help the students to be active and happy to learn (Suparno, 2013: 69). Thus, by 
incorporating creative thinking processes in all fields of content, teachers can provide 21stcentury life skills in students' creative thinking and production (Thompson, 2017).

The inquiry training model is a good learning experience for students. Physics conceptual knowledge of students using the inquiry training learning model is better than the conceptual knowledge of Physics students who use conventional learning (Harahap, Motlan, \& Siregar, 2017). Inquiry-based science learning tools are useful for enhancing creative thinking skills and work creatively with other junior high school students (Wibowo \& Laksono, 2015). This statement is also supported by research that stated that inquiry learning with handouts affects the learning outcomes of Physics (Erlinda, 2016).

Inquiry learning emphasizes the process of looking and finding. Study material is not given directly. In this case, the students have the role in looking and finding themselves, while teachers as facilitators and mentors of students in learning (Hosnan, 2016). The inquiry training model is useful in terms of arousing curiosity in students, better retention of concepts, generating interest in students, and arousing their desire to ask questions and interact in class (Chaudhari, 2015).

The teaching and learning process through inquiry always involves the students in exchanging opinions through discussions, seminars, and others. Some of the advantages of learning by using the inquiry are building an understanding of useful concepts and ideas, helping in using memory and transfer in new learning process situations, encouraging students to think and work on their initiative, helping the students to think of initiatives and formulate their hypotheses, giving the intrinsic satisfaction, and encouraging a more challenging learning process (Hosnan, 2016). The syntax of the Inquiry Training learning model is shown in Table 2 (Turnip, Wahyuni, \& Tanjung, 2016).

Table 2. Syntax of Inquiry Training Learning Model

\begin{tabular}{cl}
\hline Phase & \\
\hline 1 & Reveal the problem \\
2 & Formulate a hypothesis \\
3 & Review data and conduct experiments \\
4 & Organize, formulate and explain \\
5 & Analyze research and communication processes \\
\hline
\end{tabular}

The inquiry training learning model using visual media is better at improving students' science process skills than conventional learning (Derlina \& Nst, 2016). It is also accompanied by a statement Iftakhar (2016) which explains that teachers should be very welcoming of any new technology to ensure the best learning in virtual classrooms besides physical classes.

The role of teachers and students has changed with the changing frame of mind in education that affects the concept of learning. Older systems have been discarded, and student autonomy is essential. Information is continuously updated, shifting, and increasing. Learning Module System (LMS) is an excellent choice for teachers in controlling and providing learning materials (Cavus \& Alhih, 2014).

This activity will increase the interest of the students in the study of science. The teacher can give students something they usually cannot show in class because of a lack of time. LMS also facilitates interaction with the students in real-time as a learning community. LMS allows students to share their knowledge and difficulties so that they can help each other through forums and chat. The teacher can see in the parts the concepts are difficult to understand (Cavus \& Alhih, 2014).

Students in the blended learning group experience more significant learning outcomes compared to students in traditional approaches (Bazelais \& Doleck, 2018). Blended learning has advantages (Lalima \& Lata Dangwal, 2017). They are helping the teachers and students to get more time in class for creative and cooperative training; giving students benefit from online learning and Computer Assist Learning (CAL) without losing elements of social interaction and human touch in traditional teaching; providing more room for communication (Lalima \& Lata Dangwal, 2017). The communication cycle is resolved in blended learning, which is not possible if it only follows a traditional approach. Students become smarter in the 
field of technology, and they are more fluent in the digital language; students have more reliable professionalism when developing qualities such as self-motivation, self-responsibility, and discipline; they can update learning content and provide new life for established learning.

Google Classroom is a free application designed to help teachers and students communicate and collaborate, process paperless tasks (Bell, 2015). Google Classroom is perceived as useful and easy to use (Wijaya, 2016) and can be considered as a classroom resource program for teachers and students (Dicicco, 2016). Google Classroom is a free application designed to help teachers and students communicate and collaborate, process paperless tasks (Bell, 2015). Through the page of Google Classroom (2018), it is explained that Google Classroom is a free application designed to help teachers to save time, keep the class organized, and improve communication with students. Some of the main features in the Google Classroom are as follows: creating and organizing classes, adding teaching materials, adding students, adding announcements, assignments, discussion topics, and comments, reusing old posts, communication, attaching files, Youtube videos, links website, and Google Drive.

Physics learning can be realized in blended learning-mode, which is learning that combines face-to-face activities with online learning. Through blended learning, teachers can use the Google Classroom to help present material and facilitate understanding of learning material for students. The ease of use of Google Classroom makes it the right medium for the implementation of blended learning. Teachers are expected to be able to carry out their duties well, including more opportunities in examining and improving learning, conducting dialogue with students. The stages of inquiry training activities assisted by Google Classroom are presented in Table 3.

Table 3. Phases of Inquiry Training Learning Assisted by Google Classroom

\begin{tabular}{|c|c|c|c|}
\hline \multirow{2}{*}{ Phase } & \multirow{2}{*}{ Mode } & \multicolumn{2}{|c|}{ Creative Thinking Skills } \\
\hline & & Indicator & Description \\
\hline $\begin{array}{l}\text { Reveal the problems and formulate a } \\
\text { hypothesis }\end{array}$ & $\begin{array}{l}\text { Face to face } \\
\text { and online }\end{array}$ & Fluency & Give lots of questions \\
\hline Review data and conduct experiments & Face to face & Flexibility & $\begin{array}{l}\text { Produce various ideas, } \\
\text { answers, or questions }\end{array}$ \\
\hline Organize, formulate and explain & Face to face & Originality & $\begin{array}{l}\text { Produce new and unique } \\
\text { phrases }\end{array}$ \\
\hline $\begin{array}{l}\text { Analyze research and communication } \\
\text { processes }\end{array}$ & $\begin{array}{l}\text { Face to face } \\
\text { and online }\end{array}$ & Elaboration & $\begin{array}{l}\text { Able to enrich and build } \\
\text { ideas }\end{array}$ \\
\hline
\end{tabular}

These stages will make students actively involved in learning activities and can practice doing the investigation process through experiments/ lab work. The online learning activities are conducted to discuss related material learned. In addition to discussions, students are also given the task to work on quizzes and practice questions interactively.

\section{Method}

This research was a quasi-experimental research conducted in SMA Negeri 1 Banguntapan, Bantul District, Yogyakarta Special Province. The sample selection technique used simple random sampling. The subjects of the study were 33 students of class XI MIPA1 2017/2018 Academic Year.

The independent variable of the research was the inquiry training learning model assisted by Google Classroom, while the dependent variable is the creative thinking skills measured using the essay test instrument. Before using the essay test instrument, these creative thinking skills have been validated by material experts.

The learning was done in two modes, which were: face to face mode and online mode. The initial stage before face-to-face mode learning was the pretest. After face-to-face mode learning, the next stage was online mode learning through Google Classroom based on the agreed time with the students. The final stage was the posttest activity to measure scores on 
improving students' creative thinking skills. The following is the distribution of inquiry training learning-mode activities assisted by Google Classroom presented in Table 4.

Table 4. Inquiry Training Learning Activities Assisted by Google Classroom

\begin{tabular}{clcc}
\hline \multirow{2}{*}{ Phase } & \multicolumn{1}{c}{ Syntax } & \multicolumn{2}{c}{ Mode } \\
\cline { 3 - 4 } & & Face to Face & Online \\
\hline 1 & Reveal the problem & $\sqrt{ }$ & $\sqrt{ }$ \\
2 & Formulate a hypothesis & $\sqrt{ }$ & - \\
3 & Review data and conduct experiments & $\sqrt{ }$ & - \\
4 & Organize, formulate and explain & $\sqrt{ }$ \\
5 & Analyze research and communication processes & $\sqrt{ }$ \\
\hline
\end{tabular}

Face-to-face mode learning activities were conducted with the inquiry training model. Learning activities were designed to follow five phases, which became the syntax of the inquiry training learning model. In the process, the students were directed to prove the nature of magnifying glass by being associated with everyday life. Guided by the compiled LKPD, it was expected that the students could formulate an enlargement of shadow by magnifying glass by accommodating eyes and not accommodating eyes, categorizing the magnification of shadows, planning, and carrying out experiments to probe the magnification of shadows in the magnifying glass.

The achievement of increasing creative thinking skills could be measured using pretest scores and posttest scores. The pretest score and posttest score were calculated with the gain equation stated in the following equation (McKagan, Sayre, \& Madsen, 2017):

$$
g=\frac{S_{\text {post }}-S_{\text {pre }}}{S_{\text {maks }}-S_{\text {pre }}}
$$

Note:

$$
\begin{array}{lll}
g & : \text { Gain score } & S_{\text {maks }}: \text { Maximum score } \\
S_{\text {pre }}: & \text { Pretest score } & S_{\text {post }}: \text { Posttest score }
\end{array}
$$

Table 5. Gain Score Category

\begin{tabular}{cc}
\hline Category & Score \\
\hline High & $g>0.7$ \\
Moderate & $0.3 \leq g \leq 0.7$ \\
Low & $g<0.3$ \\
\hline & Source: (McKagan et al., 2017)
\end{tabular}

\section{Result and Discussion} 6 below:

Inquiry in Physics learning model assisted by Google Classroom is presented in Table

Table 6. Implementation of The Inquiry Training Model Assisted by Google Classroom

\begin{tabular}{ccl}
\hline Phase & Mode & \multicolumn{1}{c}{ Activity } \\
\hline 1 & $\begin{array}{l}\text { Face to face } \\
\text { and online }\end{array}$ & $\begin{array}{l}\text { The teacher displays the usage of magnifying glass video that has been } \\
\text { uploaded to Google Classroom; Ask students to retell the contents of the } \\
\text { video displayed and provide an opportunity to ask questions about what } \\
\text { has not been understood regarding the video. } \\
\text { The teacher gives questions related to the learning objectives. Students } \\
\text { respond to the teacher's questions. } \\
\text { After group division, LKPD, and practicum tools, the teacher asks the } \\
\text { students to conduct experiments following the procedures stated in the } \\
\text { LKPD. } \\
\text { The students discuss the experimental data. Representatives of the } \\
\text { students convey conclusions, then corrected together by the teacher and } \\
\text { the students. }\end{array}$ \\
3 & Face to face \\
\hline & Face to face to face &
\end{tabular}




\begin{tabular}{ccc}
\hline Phase & Mode & $\begin{array}{l}\text { Activity } \\
\text { The teacher asks the students to analyze the experimental process that } \\
\text { has been carried out and asks the students to convey the results of their } \\
\text { analysis and input related to the experimental process. The teacher } \\
\text { conveyed about online mode learning with Google Classroom and agreed } \\
\text { to the study time together with the students. }\end{array}$ \\
\hline
\end{tabular}

Note:

Phase 1: Reveal the problem

Phase 2: Formulate a hypothesis

Phase 3: Review data and conduct experiments

Phase 4: Organize, formulate and explain

Phase 5: Analyze the research and communication processes

Table 6 provides details of the implementation of the Inquiry Training model assisted by Google Classroom. The learning was carried out using the syntax of Inquiry Training model assisted by Google Classroom, which was: reveal the problems; formulate a hypothesis; review data and conduct experiments; organize, formulate and explain; and analyze the research and communication processes. The entire syntax phases of the learning had been carried out in two modes, which were face-to-face mode and online mode using Google Classroom assistance. The Google Classroom was accessed by the students using smartphones through the Google Classroom page.

\section{A. Participation of The Students in Learning}

Participation of the students in the Physics Inquiry Training learning model assisted by Google Classroom was obtained by counting the number of students who actively participate in learning activities, both face-to-face mode learning and online mode learning assisted by Google Classroom. Data on student participation in face-to-face Physics learning was calculated based on student attendance data in learning. While data on student participation in online mode learning were calculated based on data on participation in learning, starting from creating a Google Classroom account, to the stage of participating in learning activities. Recapitulation of data on student participation in the Physics Inquiry Training learning model assisted by Google Classroom is presented in Table 7.

Table 7. Level of Student Participation in Learning Activities

\begin{tabular}{clccc}
\hline \multirow{2}{*}{ No. } & \multirow{2}{*}{ Learning Activity Mode } & \multicolumn{2}{c}{ Number of Students } & Percentage \\
\cline { 3 - 4 } & & Registered & Participating & $(\%)$ \\
\hline 1 & Face to Face & 32 & 32 & 100 \\
2 & Online & 31 & 29 & 90.6 \\
\hline
\end{tabular}

Participation of students in the Physics Inquiry Training learning model assisted by Google Classroom of face-to-face mode was considered very high because the learning was followed by $100 \%$ of the students in the sample class. However, online learning-mode was followed by $90.6 \%$ students, following learning or $93.5 \%$ of the total number of students who had registered with Google Classroom. Thus, the participation of students in Inquiry Training learning is assisted by Google Classroom was high. The high level of student participation was caused by the interest in new media and the role of the teacher who emphasizes on students to participate actively. For this reason, the use of Google Classroom media can increase student participation in the implementation of blended learning.

\section{B. Test Results of Students' Creative Thinking Skills}

The creative thinking skills of the students were measured by giving questions about the pretest and posttest. The results of the pretest and posttest creative thinking skills of the students of class XI MIPA-1 SMAN 1 Banguntapan are presented in Table 8 below: 
Table 8. Scores of students' creative thinking skills test

\begin{tabular}{|c|c|c|}
\hline Result & Pretest & Posttest \\
\hline Maximum & 48 & 88 \\
\hline Minimum & 4 & 16 \\
\hline Mean & 17.1 & 43.03 \\
\hline Median & 16 & 40 \\
\hline
\end{tabular}

Based on Table 8, information is obtained that there is an increase in the score of students' creative thinking skills in the Physics Inquiry Training learning model assisted by Google Classroom. The score is a score obtained by individual students. That is that in the sample class, there are students who can obtain the maximum and minimum score for each test. Increasing of the score of the students' creative thinking skills can be seen from the increase in maximum scores, minimum scores, mean, and median score of the creative thinking skills.

Physics Inquiry Training learning model assisted by Google Classroom can increase the score of students' creative thinking skills, even though the improvement score is distributed in the high, medium, and low categories. The increase in scores is supported by the high enthusiasm of students in participating in learning both face-to-face mode and online mode through Google Classroom. The histogram graph of the maximum score achievement and the minimum score of students' creative thinking skills can be seen in Figure 1.

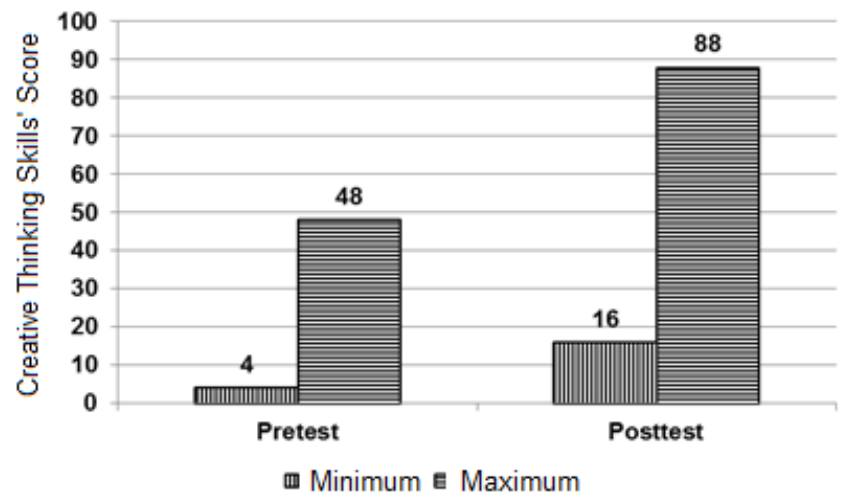

Figure 1. Achievement of The Pretest and Posttest Scores of The Creative Thinking Skills

Figure 1 provides information that the Physics Inquiry Training learning model assisted by Google Classroom can improve students' creative thinking skills. Pretest data shows that the maximum score of creative thinking skills is 48 , while the maximum posttest score of creative thinking skills is 88 . Likewise, with the minimum score of creative thinking skills, the pretest score is 4 , while the posttest score is 16 . It means that there is an increase in the achievement of maximum and minimum scores of students' creative thinking skills. This information is also supported by Figure 2, as shown below.

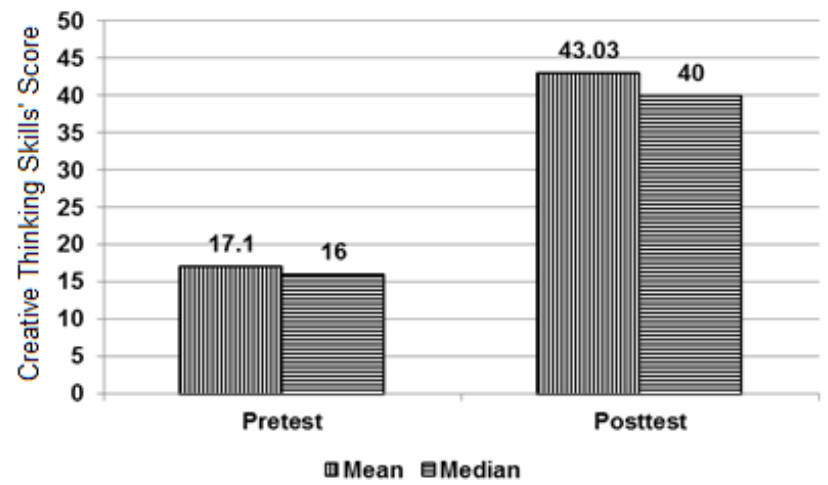

Figure 2. Histogram of Mean and Median Pretest and Posttest Score 
Figure 2 shows the increase in mean scores and median scores of students' creative thinking skills. The mean score of creative thinking skills increased from 17.1 to 43.03. The mean score of creative thinking skills increases from 16 to 40 . Based on these three indicators, it is clear that the implementation of the Inquiry Training learning model assisted by Google Classroom can improve students' creative thinking skills. The calculation is needed using the gain equation to find out the category of increasing scores of students' creative thinking skills. After going through calculations, the score of the students' creative thinking skills is obtained, which can be seen in Figure 3 below.

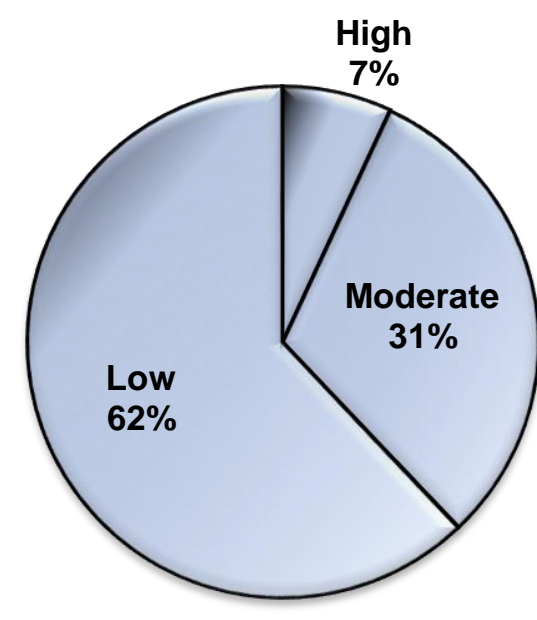

口High 口Moderate aLow

Figure 3. Pie Chart of The Gain Score Category

The pie chart in Figure 3 shows the categorization of gain scores of students' creative thinking skills obtained after taking the Physics Inquiry Training learning model assisted by Google Classroom. Students who take inquiry learning training through Google Classroom are 29 people. The results obtained that $62 \%$ of students have a low gain score, which means that the gain score of creative thinking skills is below 0.3. Students who are in the medium gain category are $31 \%$, meaning that the achievement score of the creative thinking skills is between $0.3-0.7$. While students who are in the high gain score category in the creative thinking skills test are $7 \%$, meaning that the gain score of their creative thinking skills is more than 0.7 .

Table 9. Average Gain Score for Each Indicator of Creative Thinking Skills

\begin{tabular}{lcc}
\hline \multicolumn{1}{c}{ Creative Thinking Skills } & Average of Gain Score & Category \\
\hline Fluency & 0.28 & Low \\
Flexibility & 0.64 & Medium \\
Originality & 0.16 & Low \\
Elaboration & 0.26 & Low \\
Overall & 0.3 & Medium \\
\hline
\end{tabular}

Based on Table 9, information can be obtained that the students experienced an increase in their creative thinking skills after following the Inquiry Training learning model assisted by Google Classroom. The average of gain score for each aspect was as follows: the average gain score for fluency aspect was 0.28 with a low category; the average gain score for flexibility aspect was 0.64 with the moderate category; the average gain score for originality aspect was 0.16 with a low category; the average gain score for elaboration aspect was 0.26 with a low category. It showed that the Physics Inquiry Training learning model assisted by Google Classroom could increase the score of creative thinking skills for each aspect of 
creative thinking. Although the majority was in the low category in each aspect, the flexibility aspect had a score in the moderate category. This data shows that students could experience a significant increase in the aspect of flexibility. The increase of the score of creative thinking skills of fluency and elaboration aspects was still not significant, as seen from the score, which was still in the low category score, close to the lower limit of the moderate category. As for the originality aspect, the increase in the gain score was not significant.

The overall gain score of creative thinking skills as a whole was 0.3 , which was in the moderate category. The score was at the lower limit of the gain score of moderate category. Even so, it showed that the Physics Inquiry Training learning model assisted by Google Classroom could help improve the students' creative thinking skills. The high percentage of the students with low gain categories and the average gain scores of creative thinking skills in the medium category was also influenced by several factors as follows:

1) In face-to-face mode learning, the available time was only used with practicum activities, and the practicum activities took place slowly, so the students had not been directed to the meaning and application of experimental results.

2) Online mode learning had not been appropriately used, it had not been implemented promptly classically.

3) The feedback process on online mode learning could not be done optimally, so the students did not yet know for sure whether the exercises they were working on were correct or needed improvement.

The Physics Inquiry Training learning model assisted by Google Classroom could help improve students' creative thinking scores. It is in line with the results of the study by Wibowo \& Laksono (2015), which stated that inquiry-based science learning tools are useful for enhancing creative thinking skills and improving creative thinking skills and scientific attitudes (Sandika \& Fitrihidajati, 2018). Therefore, this model can be used as an alternative in blended learning to improve students' creative thinking skills. The problem is that the achievement of the gain score is in the medium category. Although the achievement of the gain score was in the moderate category on average, the flexibility aspect could increase the score of creative thinking skills, which were close to the high category. Personally, moderate and high gain scores had been achieved by $38 \%$ of students, meaning that the learning model applied was quite significant in improving the students' creative thinking skills. It is necessary to optimize the implementation of learning classically to achieve better results. Notably, increasing the participation of group members internally in helping group members to increase knowledge.

Although the learning outcomes obtained had not been able to increase the score of creative thinking skills with a high category on average, but learning using Google Classroom had been responded positively by the students and Physics teacher. The high level of participation of the students in face-to-face and online mode learning can be evidence of the high interest in learning of the students. Apart from that, the Physics teacher was very interested in using Google Classroom media. It means that Google Classroom can be recommended as a blended learning media that is appropriate for use.

\section{Conclusion and Suggestion}

The inquiry training learning model assisted by Google Classroom can improve students' creative thinking scores. Gain achievement of students' creative thinking skills is categorized into three, which are: $62 \%$ of the students with low gain score category, $31 \%$ of the students with moderate gain score category, and $7 \%$ of the students with high gain score category. While on average, the gain score of students' creative thinking skills is 0.3 , which is in the medium category.

Further research can be carried out by considering the need to optimize the use of online mode learning with Google Classroom and activities to confirm knowledge construction in face-to-face mode learning. 


\section{References}

Bakir, S., \& Öztekin, E. (2014). Creative thinking levels of preservice science teachers in terms of different variables. Journal of Baltic Science Education, 13(2), 231-242.

Bazelais, P., \& Doleck, T. (2018). Blended learning and traditional learning: A comparative study of college mechanics courses. Education and Information Technologies, 23(6), 2889-2900. https://doi.org/10.1007/s10639-018-9748-9

Bell, B. K. (2015). Teacher' s Guide to Google's Classroom. Shake Up Learning, LLC, 1-45.

Cavus, N., \& Alhih, M. S. (2014). Learning Management Systems Use in Science Education. Procedia - Social and Behavioral Sciences, 143, 517-520. https://doi.org/10.1016/j.sbspro.2014.07.429.

Chaudhari, P. (2015). A Study of Effectiveness of Inquiry Training Model for Teaching Science to Standard VIII Student of Vadodara City. Horizons of Holistic Education, 2(September), 222-232.

Classroom, G. (2018). Classroom Help: About Google Classroom. Retrieved from https://support.ggogle.com/edu/classrooom/answer/6020279?h1=en\&ref_topic=71754 44

Corazza, G. E. (2016). Multidisciplinary Contributions to the Science of Creative Thinking. (S. Agnoli, Ed.). Singapore: Springer.

Derlina, \& Nst, L. A. (2016). Efek Penggunaan Model Pembelajaran Inquiry Training Berbantuan Media Visual Dan Kreativitas Creativity-Assisted Inquiry Training Learning Model on Students ' Science Process Skills. Jurnal Cakrawala Pendidikan, 15(2), 153163. https://doi.org/10.21831/cp.v15i2.8080

Dicicco, K. M. (2016). Rowan Digital Works The effects of Google Classroom on teaching social studies for students with learning disabilities. Retrieved from http://rdw.rowan.edu/etd

Erlinda, N. (2016). Penerapan Metode Pembelajaran Inkuiri Disertai Handout: Dampak Terhadap Hasil Belajar Fisika Siswa SMAN 1 Batang Anai Padang Pariaman. Jurnal IImiah Pendidikan Fisika Al-Biruni, 5(2), 223-231. https://doi.org/10.24042/jpifalbiruni.v5i2.122

Hanni, I. U., Muslim, Hasanah, L., \& Samsudin, A. (2018). K-11 students' creative thinking ability on static fluid: A case study. Journal of Physics: Conference Series, 1013(1), 07. https://doi.org/10.1088/1742-6596/1013/1/012034

Harahap, R., Motlan, \& Siregar, N. (2017). Pengaruh Model Pembelajaran Inquiry Training Berbantuan Mind Map Terhadap Pengetahuan Konseptual dan Keterampilan Proses Sains (KPS) Siswa. Jurnal Pendidikan Fisika, 6(2), 76-81. Retrieved from http://jurnal.unimed.ac.id/2012/index.php/jpf

Hosnan, M. (2016). Pendekatan Saintifik dan Kontekstual dalam Pembelajaran Abad 21: Kunci Sukses Implementasi Kurikulum 2013. Bogor: Ghalia Indonesia.

Iftakhar, S. (2016). Google classroom: what works and how? Journal of Education and Social Sciences, 3, 12-18. https://doi.org/10.1002/eji.201344328

Klieger, A., \& Sherman, G. (2015). Physics textbooks: Do they promote or inhibit students' creative thinking. Physics Education, 50(3), 305-309. https://doi.org/10.1088/00319120/50/3/305

Lalima, \& Lata Dangwal, K. (2017). Blended Learning: An Innovative Approach. Universal Journal of Educational Research, 5(1), 129-136. https://doi.org/10.13189/ujer.2017.050116

Malik, A., Setiawan, A., Suhandi, A., \& Permanasari, A. (2017). Enhancing pre-service physics teachers' creative thinking skills through HOT lab design. AIP Conference Proceedings, 1868(August). https://doi.org/10.1063/1.4995177

McKagan, S., Sayre, E., \& Madsen, A. (2017). Normalized gain: What is it and when and how should I use it? Retrieved February 3, 2019, from https://www.physport.org/recommendations/Entry.cfm?ID=93334

Nurcahyanto, E., \& Supahar. (2015). Development of STEM-Based Performance Assessment in Physics Learning for Student's Creative Thinking Skill. Proceeding of International Seminar on Science Education, Yogyakarta State University. 
Sandika, B., \& Fitrihidajati, H. (2018). Improving creative thinking skills and scientific attitude through inquiry-based learning in basic biology lecture toward students of biology education. JPBI (Jurnal Pendidikan Biologi Indonesia), 4(1), 23-28. https://doi.org/10.22219/jpbi.v4i1.5326

Suparno, P. (2013). Metodologi Pembelajaran Fisika Konstruktivistik dan Menyenangkan: Edisi Revisi (Kedua). Yogyakarta: Universitas Sanata Dharma Yogyakarta.

Thompson, T. (2017). Teaching Creativity Through Inquiry Science. Gifted Child Today, 40(1), 29-42. https://doi.org/10.1177/1076217516675863

Turnip, B., Wahyuni, I., \& Tanjung, Y. I. (2016). The Effect of Inquiry Training Learning Model Based on Just in Time Teaching for Problem Solving Skill. Journal of Education and Practice, 7(15), 177-181. Retrieved from https://iiste.org/Journals/index.php/JEP/article/view/30888

Wibowo, A., \& Laksono, E. W. (2015). Pengembangan dan Implementasi Perangkat Pembelajaran IPA Berbasis Inquiry. Jurnal Inovasi Pendidikan IPA, 1(2), 102-114. https://doi.org/10.21831/jipi.v1i2.7492

Wijaya, A. (2016). Analysis of factors affecting the use of google classroom to support lectures. The 5th International Conference on Information Technology and Engineering Application, (February), 61-68. Retrieved from http://eprints.binadarma.ac.id/2777/

Yusnaeni, Y., Corebima, A. D., SUsilo, H., \& Zubaidah, S. (2017). Creative Thinking of Low Academic Student Undergoing Search Solve Create and Share Learning Integrated with Metacognitive Strategy. International Journal of Instruction, 10 No. 2, 245-262. https://doi.org/https://doi.org/10.12973/iji.2017.10216a 